\begin{tabular}{|l|l|l||}
\hline \multicolumn{2}{|c|}{ PublisherInfo } \\
\hline \hline PublisherName & $:$ & BioMed Central \\
\hline \hline PublisherLocation & $:$ & London \\
\hline \hline PublisherImprintName & $:$ & BioMed Central \\
\hline \hline
\end{tabular}

\title{
Versican modulates cellular responses
}

\begin{tabular}{|l|l|l||}
\hline \multicolumn{2}{|c|}{ ArticleInfo } \\
\hline \hline ArticleID & $:$ & 1615 \\
\hline \hline ArticleDOI & $:$ & $10.1186 /$ rr-2001-68531 \\
\hline \hline ArticleCitationID & $:$ & 68531 \\
\hline \hline ArticleSequenceNumber & $:$ & 26 \\
\hline \hline ArticleCategory & $:$ & Paper Report \\
\hline \hline ArticleFirstPage & $:$ & 1 \\
\hline \hline ArticleLastPage & $:$ & 4 \\
\hline \hline & & RegistrationDate : 2001-9-18 \\
& $:$ & Received \\
\hline ArticleHistory & & Accepted 2001-9-18 \\
& $:$ 2001-9-18 \\
\hline \hline ArticleCopyright & $:$ & Biomed Central Ltd2001 \\
\hline \hline ArticleGrants & $:$ & \\
\hline \hline \hline ArticleContext & $:$ & 129312211 \\
\hline \hline
\end{tabular}


Alaina J Ammit, ${ }^{\text {Aff1 }}$

Corresponding Affiliation: Aff1

Aff1 Faculty of Pharmacy, University of Sydney, NSW, Australia

\section{Keywords}

Chemokines, ECM, proteoglycans, versican

\section{Context}

Proteoglycans are proteins with covalently linked glycosaminoglycans (GAGs). Because GAGs such as heparan sulfate (HS) and chondroitin sulfate (CS) are negatively charged, proteoglycans are able to bind many positively charged molecules, including chemokines. Recently, HS proteoglycans have been shown to promote presentation of chemokines to their specific receptors and to potentiate cellular signalling. CS proteoglycans may also have this function. The aim of this study was to examine the ability of versican, a CS proteoglycan secreted into the extracellular matrix (ECM) by a variety of cells, to bind a large panel of chemokines and the biological consequences of such binding.

\section{Significant findings}

Versican binds a variety of chemokines, including (amongst others) secondary lymphoid tissue chemokine (SLC). GAG-degrading enzymes (chrondroitinases) attentuate binding of SLC to versican, thus confirming that versican binds chemokines in a GAG-dependent manner. Rather than potentiating chemokine-induced responses, versican downregulates the integrin-mediated cell adhesion induced by SLC as well as chemokine-induced intracellular $\mathrm{Ca}^{2+}$ mobilization. The authors conclude that versican binds specific chemokines through its CS chains but that the binding tends to downregulate chemokine function. The inhibitory mechanism remains unclear, versican allows SLC to bind its receptor even after forming a complex with SLC, but inhibits transduction of an appropriate signal.

\section{Comments}


Airway remodelling, a key feature of persistent asthma, is typified by the deposition ECM proteins in the airways. In postmortem tissue from patients with severe asthma there exists a marked deposition of versican in airway wall ECM (see Additional information [1]). Versican is also significantly increased in atopic asthmatics and has been correlated with airway responsiveness (see Additional information [2]). Furthermore, it has been shown that human airway smooth muscle cells secrete versican, along with other ECM proteins, suggesting a cellular source for this proteoglycan in airways (see Additional information [3]). Taken together, these reports suggest that proteoglycans such as versican may play a role in ECM pathophysiology in asthma. In the study reviewed in this report, the known biological roles of versican (such as promotion of chrondocyte proliferation [see Additional information $\{4\}$ ] and potentiation of chemokine signalling) are extended to include negative regulation of chemokine function, suggesting that versican in airway ECM could have both proinflammatory and antiinflammatory roles in regulating airway remodelling in asthma.

\section{Methods}

Dot blot analysis, ELISA, cell adhesion assay, $\mathrm{Ca}^{2+}$ mobilization assay, radioligand binding assay

\section{Additional information}

1. Roberts CR: Is asthma a fibrotic disease? Chest 1995, 107:111S-117S.

2. Huang J, Olivenstein R, Taha R, Hamid Q, Ludwig M: Enhanced proteoglycan deposition in the airway wall of atopic asthmatics. Am J Respir Crit Care Med 1999, 160:725-729.

3. Johnson PRA, Black JL, Carlin S, Ge Q, Underwood PA: The production of extracellular matrix proteins by human passively sensitized airway smooth-muscle cells in culture: the effects of beclomethasome. Am J Respir Crit Care Med 2000, 162:2145-2151.

4. Zhang Y, Cao L, Kiani C, Yang BL, Hu W, Yang BB: Promotion of chondrocyte proliferation by versican mediated by G1 domain and EGF-like motifs. J Cell Biochem 1999, 73:445-457. 


\section{References}

1. Hirose J, Kawashima H, Yoshie O, Tashiro K, Miyasaka M: Versican interacts with chemokines and modulates cellular responses. J Biol Chem. 2001, 276: 5228-5234.

This PDF file was created after publication. 